\title{
Temperature structure and characteristics appearing on SSM/I images of the Cosmonaut Sea, Antarctica
}

\author{
TAKATOSHI TAKIZAWA, \\ Japan Marine Science and Technology Center, 2-15 Natsushima, 1okosuka 237, Japan \\ KAY I. OHSHIMA, \\ Institute of Lowe Temperature Science, Hokkaido Lniversity, Sapporo 060, Japan \\ SHLKi Ushio, \\ National Institute of Polar Research, Itabashi, Tokyo 173, Japan \\ TOSHIYUKI KAWAMURA, \\ Institute of Low Temperature Science, Hokkaido University, Sapporo 060, Japan \\ HiRoyuki Exomoto \\ Kitami Institute of Technology, Koencho 165, Kitami, Hokkaido 090, Japan
}

\begin{abstract}
Water-temperature structure in the Cosmonaut Sea at $6068^{\circ} \mathrm{S}, 35$ $65^{\circ} \mathrm{E}$ in $1987-92$ shows that cold water with a temperature below $-1.5^{\circ} \mathrm{C}$ was present in the coastal region. The Circumpolar Deep Water with a temperature higher than $1.0^{\circ} \mathrm{C}$ was found below about $150 \mathrm{~m}$ depth from northeast to northwest of the coldwater area. The SSM/I images in 1987-91 indicate that polynya activities were intensive in 1988 and the typical Cosmonaut Polynya was observed; due to weaker activities, the small and sporadic Cosmonaut Polynya formed in 1987, 1989, 1990 and 1991. A coastal polynya was frequently observed every year at about $66^{\circ} \mathrm{S}, 50-60^{\circ} \mathbf{E}$. $A$ train of polynyas to the east of Cosmonaut Polynya often appeared. It is considered that the Atmospheric Convergence Line and Antarctic Divergence Region are responsible for polynya activities in the Cosmonaut Sea.
\end{abstract}

\section{INTRODUGTION}

Polynyas are ice-free or thin-ice arcas that appear within a vast icc cover in the polar oceans. They are of interest to polar oceanography, because they greatly change the nature of air-sea interaction in the icc-covered regions. Heat and vapor transport from the open-water surface can lead to local climatologic modifications, and the icefree area can be an oasis for biological activity.

Cosmonaut Polynya has been frequently obscrved around $66^{\circ} \mathrm{S}, 45^{\circ} \mathrm{E}$ off Enderby Land from satellites since 1973 Comiso and Gordon, 1987). However, there are only very few oceanographic observations in this area. The cruise track of the Japanese Antarctic research vesscl Shirase has crossed the polynya area since 1987, which gives an accumulation of oceanographic data.

As a part of the Japanese Antarctic Climate Research program, we conducted an air-sea interaction study in 1990 92. One of the major objects of this program was to clarify the formation and maintenance mechanisms for Cosmonaut Polynya. The greater part of available oceanographic data in this area is the water temperature with XB'l in austral summers. In this paper, on the basis of the water-temperature data obtained by the Japanese Antarctic Rescarch Expedition (JARE) with XBT for the 1987.92 austral summers and the SSM/I images during $1987-91$, we describe the results of the thermal structurc of the Cosmonaut Polynya region and some features appearing on the SSM/I images. We could not avoid inferring the winter sea conditions from summer data. However, it is reasonable that the intermediate and deep waters retain winter characteristics, because the summer heating is most likely limited to the surface layer.

\section{THERMAL STRUCTURE}

Figure 1 indicates locations of XB'I' stations during 198792 used in this study. The XBT observations were restricted to one transect each year, but two transects were obtained in 1990. Three sections $\mathrm{D}^{-\mathrm{D}^{\prime}}$ in $1990, \mathrm{~B}-\mathrm{B}^{\prime}$ in 1991 and K $\mathrm{K}^{\prime}$ in 1992 in the figure were taken for the purpose of traversing the Cosmonaut Polynya area. The XBT observations along these sections were carried out at short intervals, so that we could see the detailed tempcrature structure. The cast-west temperature sections in March 


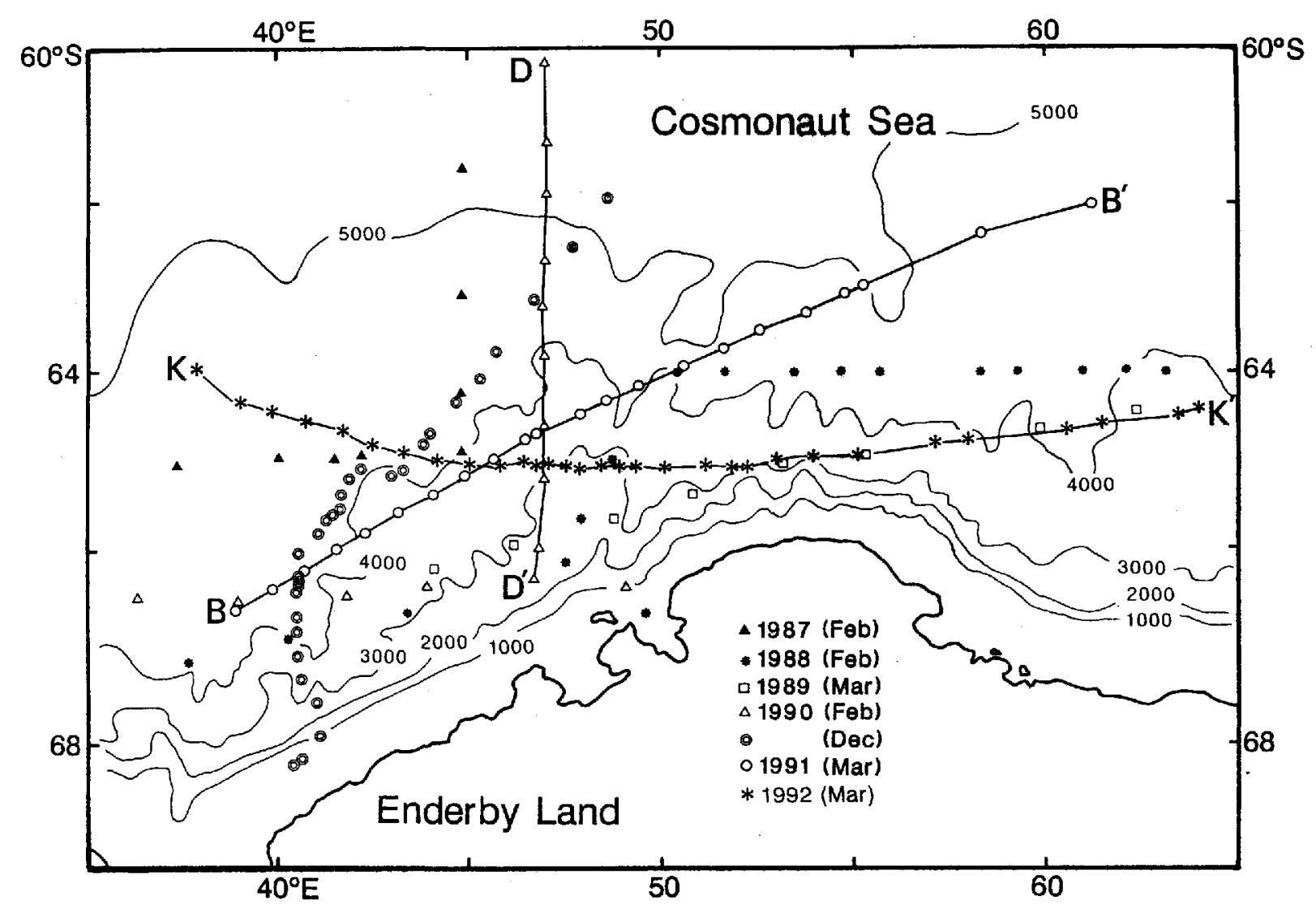

Fig. 1. Locations of XBT stations. The depth contour interval is $1000 \mathrm{~m}$. The sections $D D^{\prime}, B-B^{\prime}$ and $K-K^{\prime}$ were oblained in 1990, 1991 and 1992, respectively.

$1991\left(\mathrm{~B}-\mathrm{B}^{\prime}\right)$ and $1992\left(\mathrm{~K}-\mathrm{K}^{\prime}\right)$ are illustrated in Figures 2 and 3 , respectively. The Circumpolar Deep Water (CDW) with a temperature higher than $1.0^{\circ} \mathrm{C}$ is found between about 150 and $1000 \mathrm{~m}$ depth except at $45-50^{\circ} \mathrm{E}$. The north-south temperature section in February 1990 is shown in Figure 4. The CDW is seen in the north of the

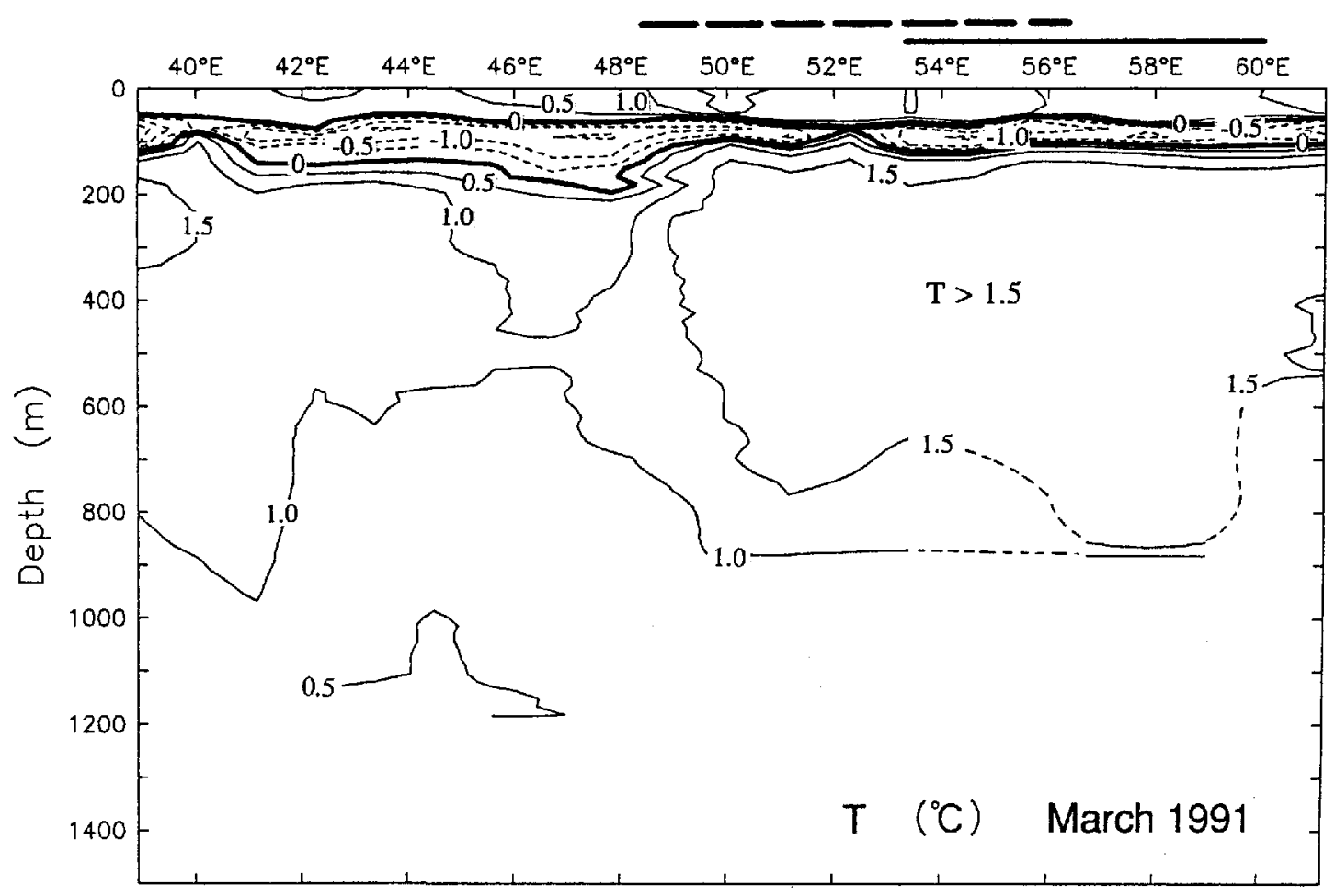

Fig. 2. Temperature section along line B-B' in Figure 1. March 1991. Heavy, solid and dashed lines above the abscissa indicate the locations of Cosmonaut Polynya appearing in Figures $9 \mathrm{c}$ and 10b, respectively. 


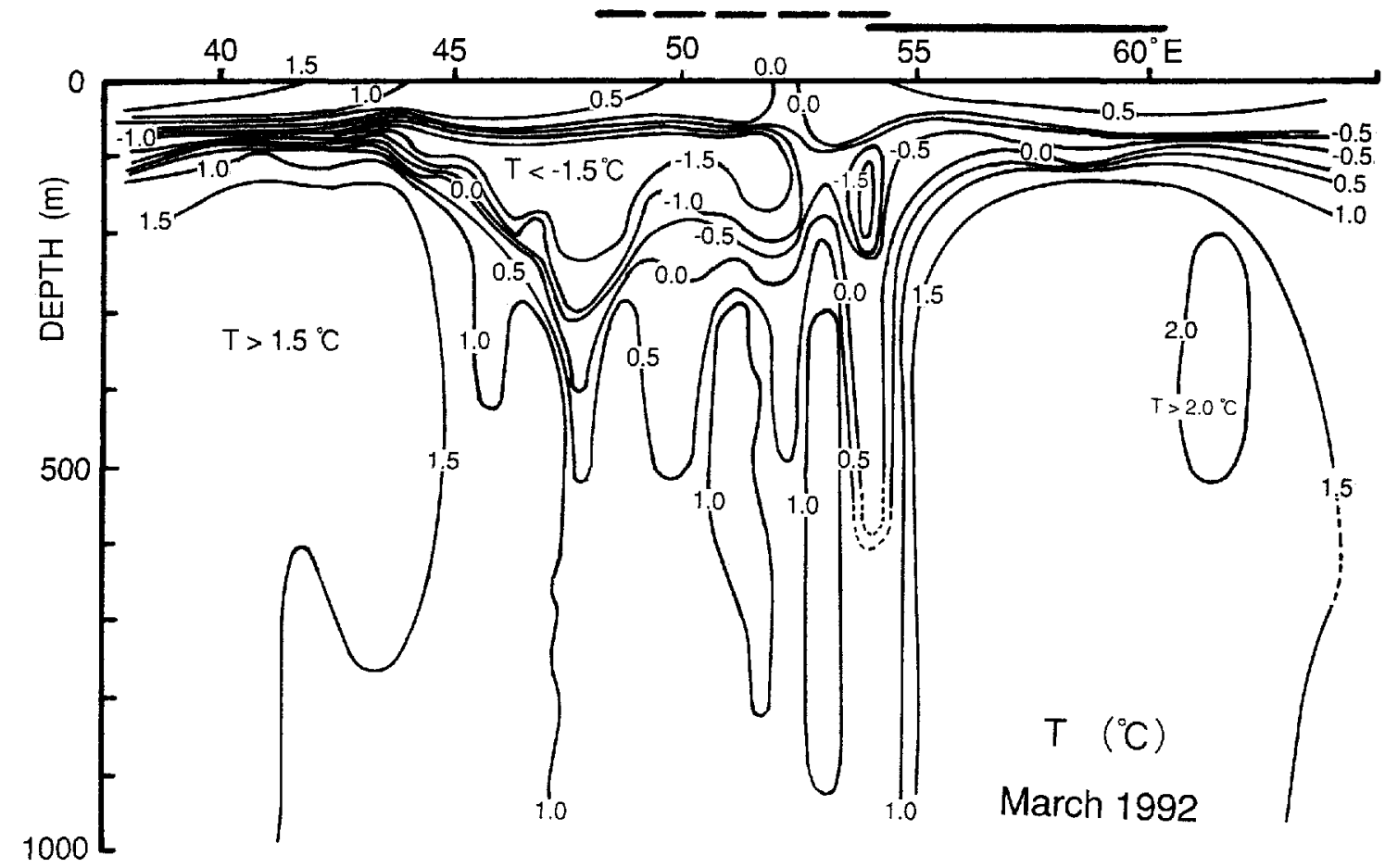

Fig. 3. Temperalure setion along line $K-K^{\prime}$ in Figure 1. March 1992. Heavy, solid and dashed lines above the abscissa indicate the locations of Cosmonaut Polynya appearing in Figures $9 c$ and $10 b$, respectizely.

scction, and cold water with a tempcrature below $-1.5^{\circ} \mathrm{C}$ is located at a depth of about $100400 \mathrm{~m}$ around $66^{\circ} \mathrm{S}$. This cold water is the Winter Water (WW) formed by cooling during winter. The shallowing of the $1.0^{\circ} \mathrm{C}$ isopleth at about $63^{\circ} \mathrm{S}$ suggests the upwelling of $\mathrm{CDW}$. Figures 2-1 show typical examples and the other sections which are not presented here indicate a similar structure.

Figure 5 illustrates the horizontal tempcrature distribution on the $200 \mathrm{~m}$ surface which was composed of all the data during 1987 92. The cold WW with a temperature below $-1.5 \mathrm{C}$ spreads over the contincntal shelf region and it extends offshore along the bottom topography at $4550^{\circ} \mathrm{E}$ (see Fig. 1). On the offshore side of it, CDW is present. Khimitsa (1976) showed the gcostrophic circulation over $30-95^{\circ} \mathrm{E}$ in the Cosmonaut

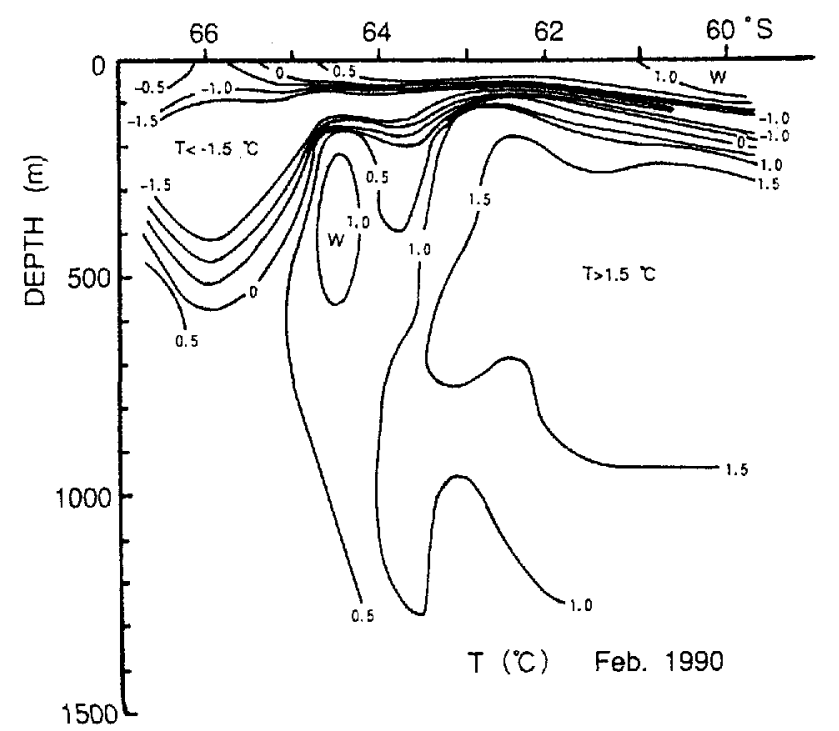

Fig. 4. Temperature section along line $D-D^{\prime}$ in Figure 1. February 1990.
Sea in the austral summer and winter of 1972-73. A strong meandering eastward flow was demonstrated at $60-68^{\circ} \mathrm{S}$. He pointcd out that the bottom topography was responsible for the meandering. Although no temperature distribution was given in his paper, it is inferred that CDW intruded southward about $45^{\circ}$ and $60^{\circ} \mathrm{E}$. Naganobu (1991) showed a similar flow pattern in the ausiral summer of 1980-81 (Fig. 7c). Hence, it is reasonably concluded that the warm area in Figure $\overline{5}$ is a manifestation of the flow of CDW. As described later, this indicates that the warm arca is a pre-conditioned area for polynya generation.

Figure 6 shows the horizontal distribution of depth of the $-1.5^{\circ} \mathrm{C}$ isopleth which was composed of all the data during 1987-92. When there were two depths at the same station, the deeper one was adopted. 'l'his figure represents the thickness of WW. An area deeper than $300 \mathrm{~m}$ is found along the coast. The thick WW is attributable to the pile-up of WW by Ekman transport due to the predominant easterly wind in the coastal region and/or to active winter cooling there. At present, however, we cannot evaluate which is more substantial, because of insufficient data. To the north of $65^{\circ} \mathrm{S}$, there are two arcas where the $-1.5^{\circ} \mathrm{C}$ isopleth was not observed (shaded areas in Figure 6).

Cosmonaut Polynya is believed to be a typical sensible-heat polynya. Comiso and Gordon (1987) elucidated the existence of localized doming of the pycnocline in the Cosmonaut Sea. This brings warmer and saltier CDW closer to the sea surface, which is an effective pre-conditioner for deep convection. The pycnocline shallowing pre-conditions the watcr there for polynya generation. The detailed pycnocline structure in the Cosmonaut Sea has not been investigated, because of the scarcity of temperature and salinity data. Naganobu (1991) demonstrated that the warmer and saltier CDW 


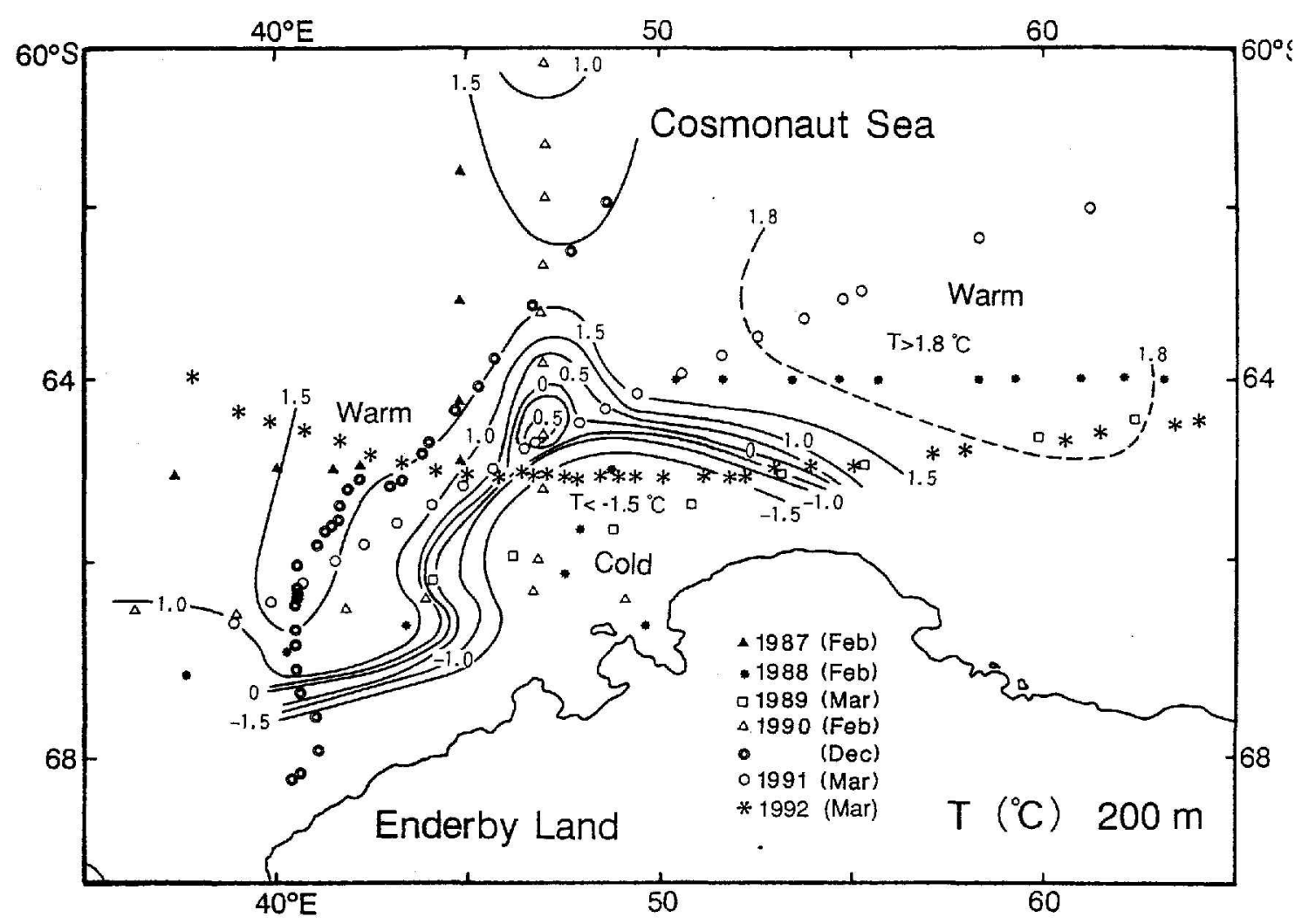

Fig. 5. Temperature distribution on the $200 \mathrm{~m}$ surface which was composed of the dala during 1987-92.

spread zonally on the $100 \mathrm{~m}$ surface over $30-120^{\circ} \mathrm{E}$ in the austral summer of $1980-81$ (Fig. 7). He concluded that the shallower pycnocline zone was induced by the upwelling of CDW in the Antarctic Divergence Region
(ADR). The elevated $1.0^{\circ} \mathrm{C}$ isopleth at $63^{\circ} \mathrm{S}$ in Figure 4 should be traced to the shallower pycnocline. Furthermore, it is considered that the warm areas in Figure 5 were related to the upwelling of CDW at ADR.

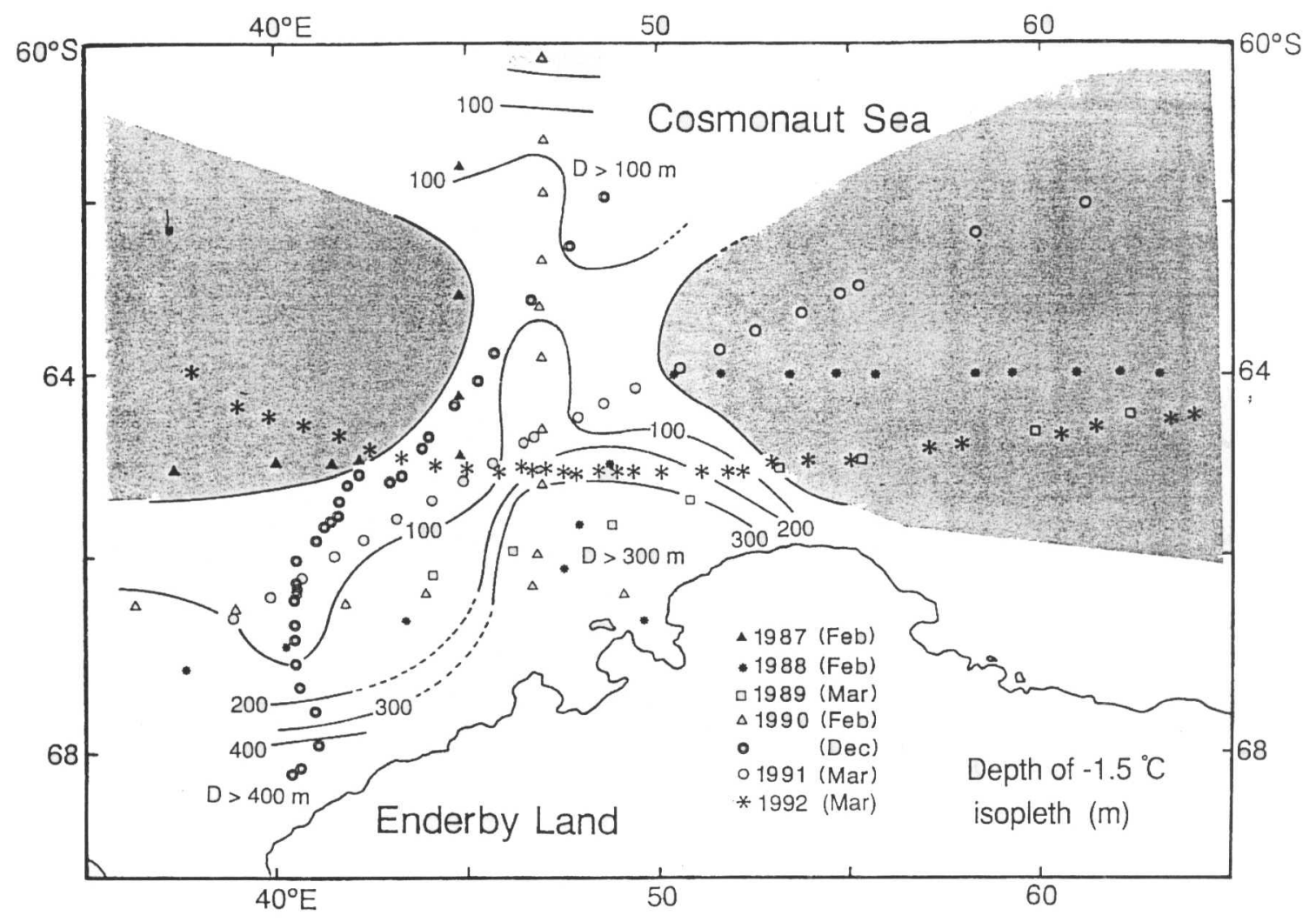

Fig. 6. Horizontal distribution of depth of the $-1.5^{\circ} \mathrm{C}$ isopleth which was composed of the data during 1987-91. Shaded areas are the regions where the $1.5^{\circ} \mathrm{C}$ isopleth was nol found. 

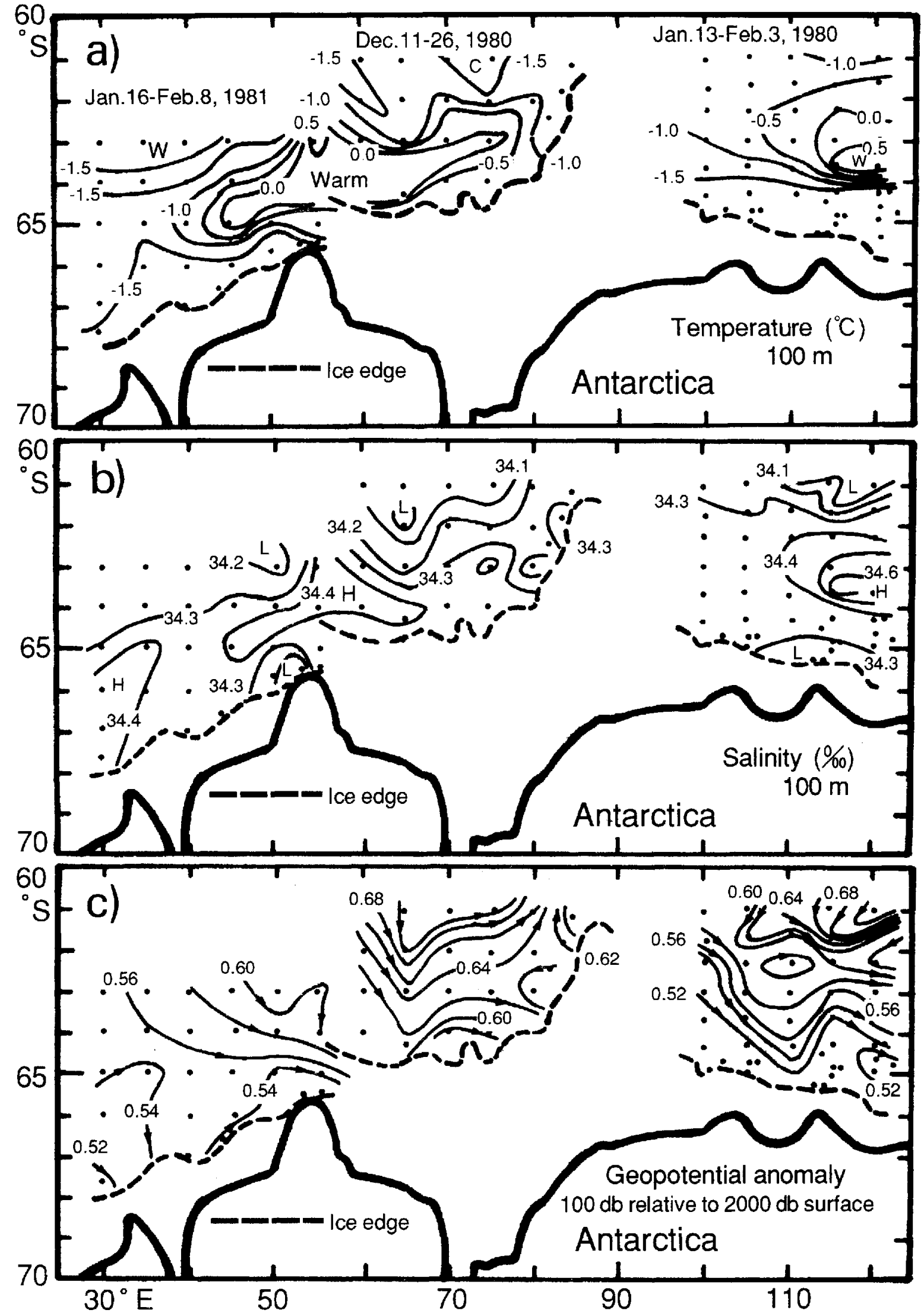

Fig. 7. Temperature (a) salinity (b) and geopotential anomaly (c) distributions on the $100 \mathrm{~m}$ surface at $30-120^{\circ} \mathrm{E}$ of the Soulhern Ocean in the austral summer of 1980-81. (Naganobu, 1991). 
Takizawa and others: Temperature structure and characteristics of Cosmonaut Sea, Antarctica
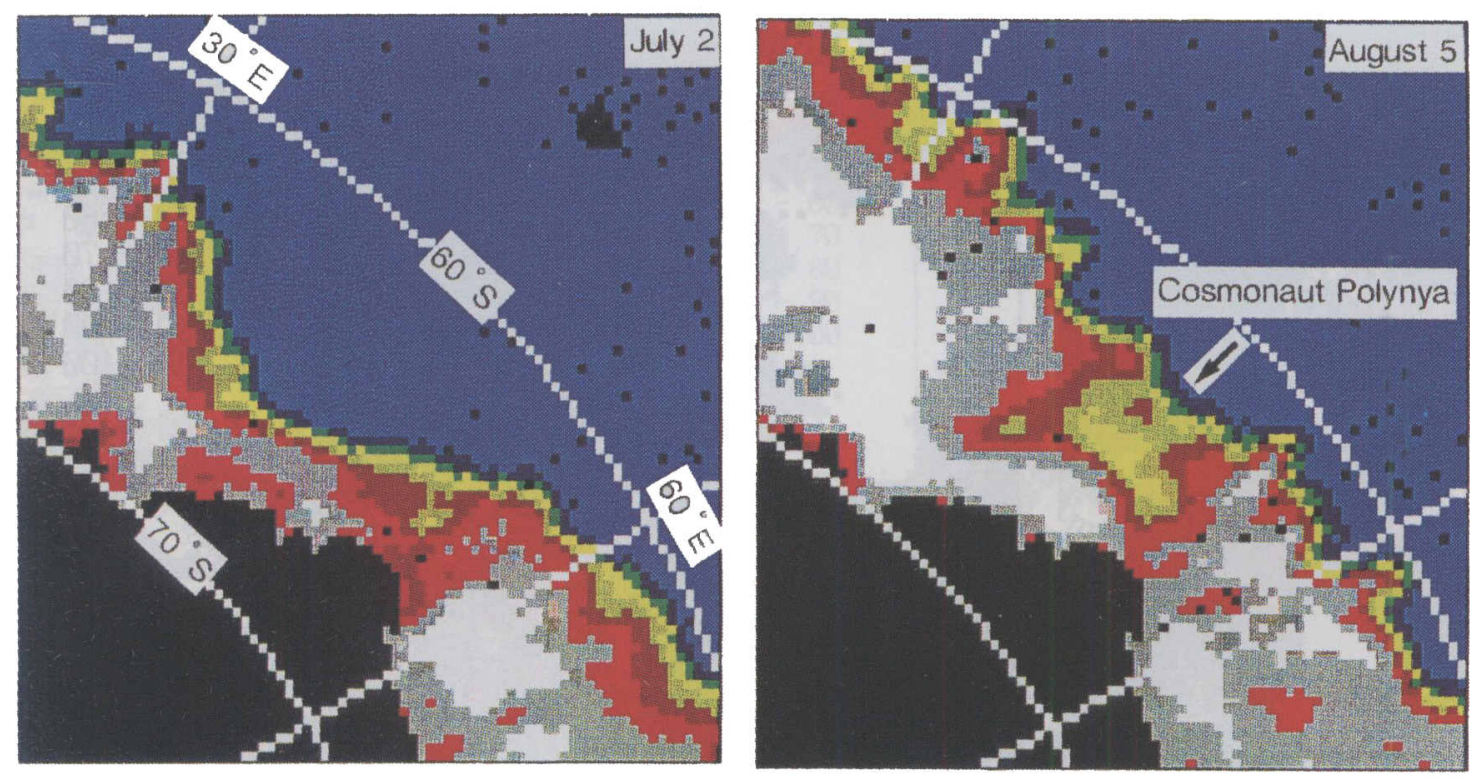

\begin{tabular}{|c|c|c|} 
CONC. $(\%)$ \\
$0-14$ \\
$15-30$ \\
$31-40$ \\
$41-50$ \\
$51-60$ \\
$61-70$ \\
$71-80$ \\
$81-90$ \\
$91-100$
\end{tabular}
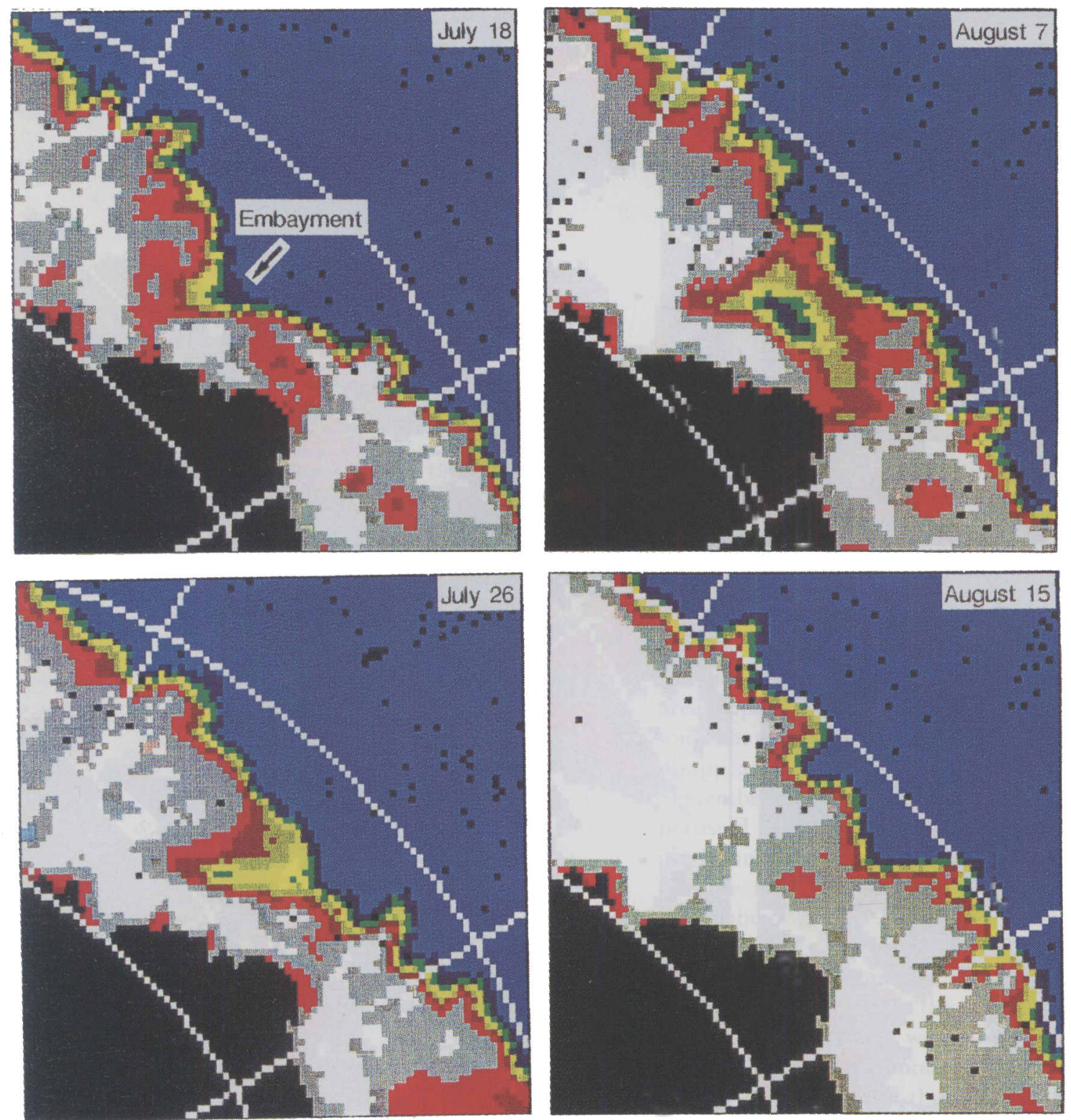

Fïg. 8. Daily SSM/I images from 2 July to 14 Oclober 1988. 

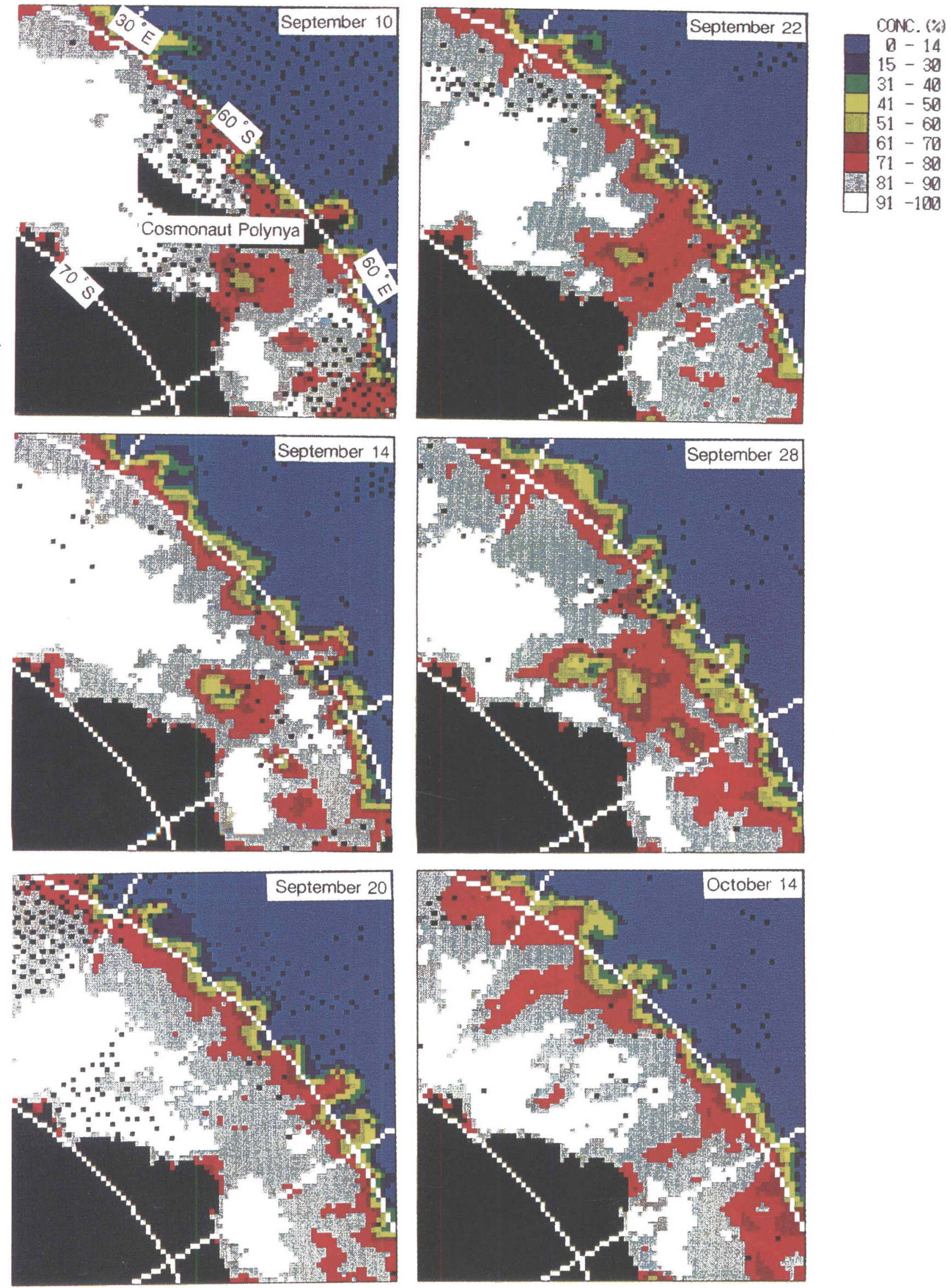

\section{CHARAGTERISTICS OF THE POLYNYAS APPEARING ON THE SSM/I IMAGE}

The SSM/I data used in this study were the DMSP SSM/I sea-ice concentration grids generated using the NASA T'am algorithm provided by the National Snow and Ice
Data Center, University of Colorado, Boulder, Colorado. We prepared a data set of ice-concentration maps during 1987 to 1991 of the sector $0-90^{\circ} \mathbf{E}$ in the Southern Ocean using image-processing software SSMIICE. The series of images reveals the occurrence of Cosmonaut Polynya. Figure 8 shows a sequence of images for 2 July-14 October 

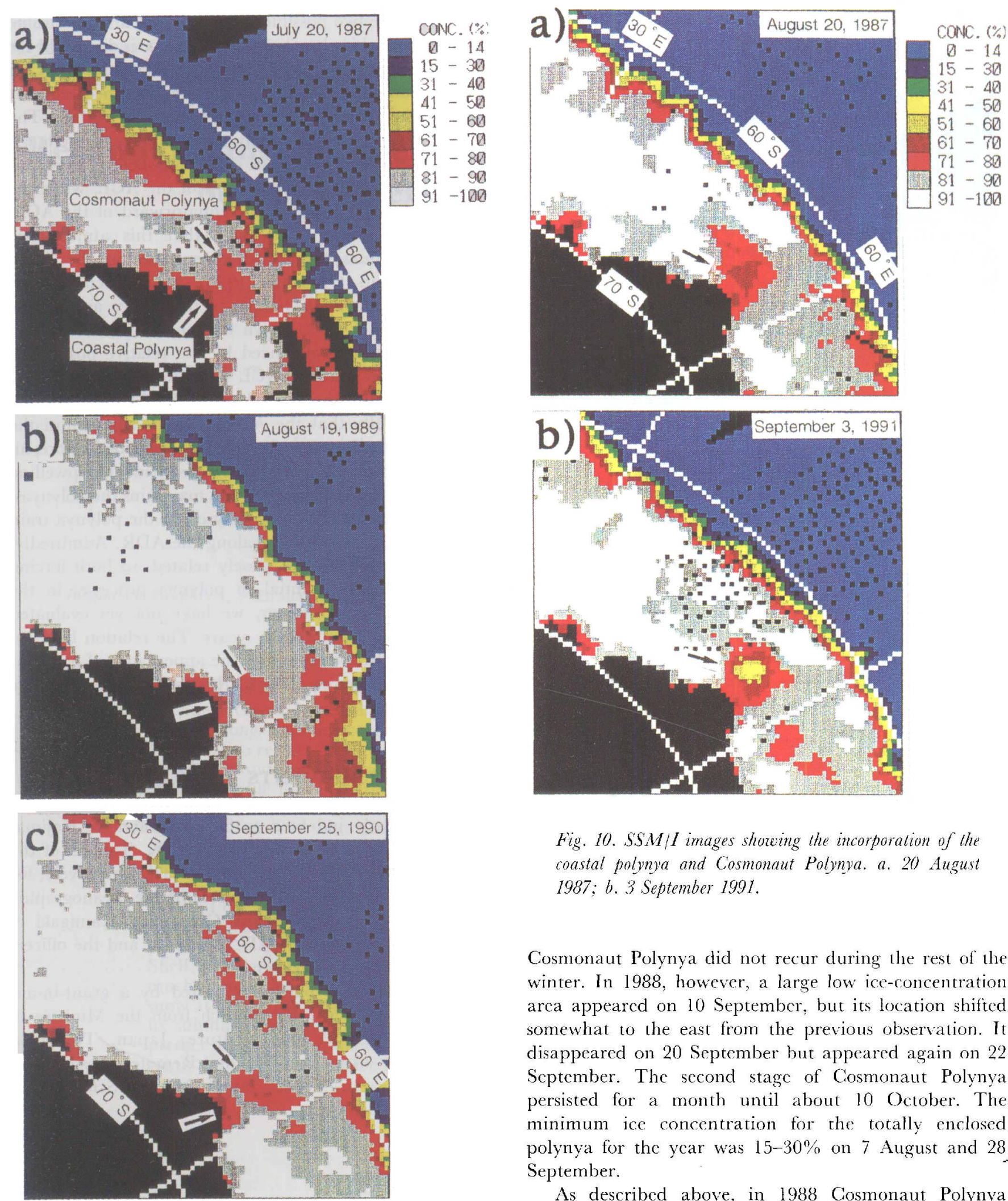

Fig. 10. SSM/I images showing the incorporation of the coastal polynya and Cosmonaut Polvnya. a. 20 August 1987; b. 3 September 1991.

Cosmonaut Polynya did not recur during the rest of the winter. In 1988, however, a large low ice-concentration arca appearcd on 10 September, but its location shifted somewhat to the east from the previous observation. It disappeared on 20 September but appeared again on 22 Scptember. The second stage of Cosmonaut Polynya persisted for a month until about 10 October. The minimum ice concentration for the totally enclosed polynya for the ycar was 15-30\% on 7 August and 28 September.

As described above, in 1988 Cosmonaut Polynya

Fïg. 9. SSM/I images showing a coastal polynya and Cosmonaul Polynya. a. 20 fuly 1987; b. 19 August 1989; c. 25 September 1990.

1988. A low ice-concentration embayment started to form at about $65^{\circ} \mathrm{S}, 45^{\circ} \mathrm{E}$ on $18 \mathrm{July}$. The pack-ice with a concentration of $61-80 \%$ enclosed it and Cosmonaut Polynya was completed on 7 August. After that, the polynya rapidly shrank and it became indeterminate on 15 August. This evolution is similar to that in 1980 demonstrated by Comiso and Gordon (1987). In 1980, began with the formation of an embayment of low iceconcentration area near the ice edge. On the other hand, no distinct cmbayment was found in 1987, 1989, 1990 and 1991. The small Cosmonaut Polynya formed suddenly within the ice cover in those years (Fig. 9) and repeated its appearance and disappearance. Thus, we can make the following statement. Polynya activities were intensive in 1988, and the typical Cosmonaut Polynya was observed; due to weaker activities, the small and sporadic Cosmonaut Polynya formed in 1987, 1989, 1990 and 1991. However, we cannot draw any clear relations between the locations of Cosmonaut Polynya and the 

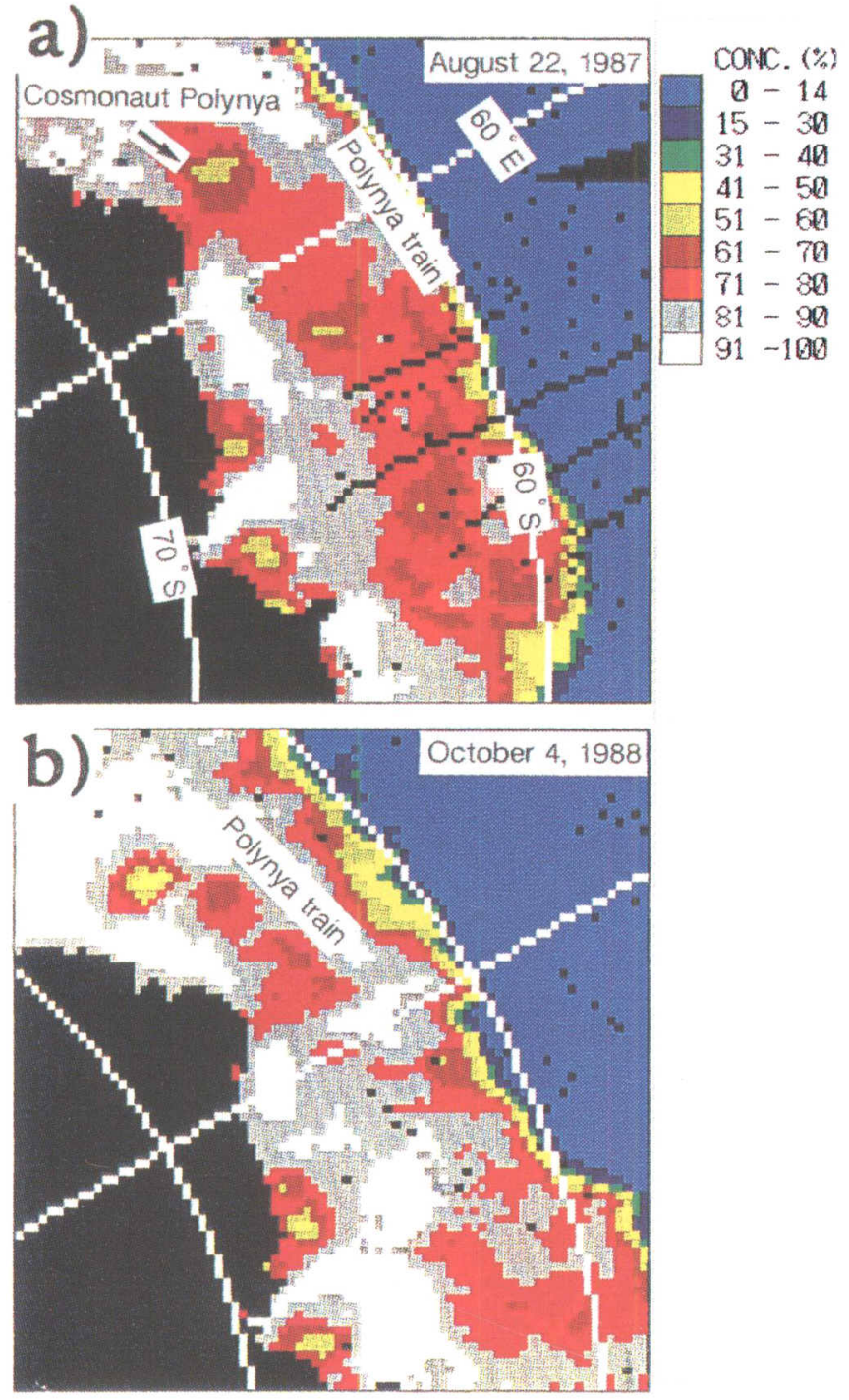

Fig. 11. Polynya train. a. 22 August 1987; b. 4 October 1988.

temperature structure of previous and/or following summers.

A coastal polynya forms frequently every year at about $66^{\circ} \mathrm{S}, 5060^{\circ} \mathrm{E}$ (Fig. 9). It does not persist throughout the winter but it repcats its appearance and disappearance. Its size, shape and duration time are subject to wide variations. It is probable that this polynya is maintained by strong offshore winds from Antarctica and is a typical latent-heat polynya. Tentatively, we have named it the coastal Cosmonaut Polynya. Cosmonaut Polynya and coastal Cosmonaut Polynya frequently appear at the same time (Fig. 9). In addition, two polynyas occasionally join in forming a large polynya (Fig. 10).

\section{POLYNYA TRAIN}

A train of polynyas has appeared from about $40^{\circ}$ to $90^{\circ} \mathrm{F}$ every year (Fig. 11). Cosmonaut Polynya is situated at the west end of the train. Reduction in ice concentration along the train is noticeable in spring. It is probable that the ice break-up in spring starts at specific locations along the zone where the polynya train forms. We can expect that there are two possible forcings which are responsible for preferential ice break-up: namely, one is due to the ice divergence around the Atmospheric Convergence Line (ACI.) and the other due to an enhanced oceanic heat flux at the Antarctic Divergence Region (ADR). The ACL indicates approximately the boundary of the mean zonal geostrophic wind. The east component is dominant in the mean wind field poleward of the ACL, while the west component is dominant equatorward of the ACL. Accordingly, it is most likely that this atmospheric condition causes the ice divergence along the ACL. Enomoto and Ohmura (1990) have discussed the temporal and spatial changes in the sea-ice area in the Antarctic. They have shown that the ice extent and ice concentration are influenced by the relative position of the ACL, and that the ACL was situated at about 66$68^{\circ} \mathrm{S}$ during March-November in 1982-84. It is expected climatologically that the ADR is located in almost the same latitudinal zone as the ACL. As described before, an enhanced oceanic heat flux associated with the upwelling of CDW at the ADR triggers and maintains the polynyas. Hence, this oceanic forcing may cause the polynya train and the early ice break-up along the ADR. Admittedly, the ACL and ADR are closely related, so both forcing cffects can be substantial in polynya processes in the Cosmonaut Sea. However, we have not yet evaluated their locations in the study years. The relation between the ACL/ADR locations and the appearance of polynyas in the Cosmonaut Sea is the subject of a future investigation.

\section{ACKNOWLEDGEMENTS}

We are greatly indebted to $\mathrm{S}$. Ikeda and T. Kojima, H. Nakamura and K. Noguchi, and K. Tanaka of the summer parties of JARE-31, 32 and 33, respectively, for their helpful support and for providing the oceanographic data. We also wish to thank Captain T. Kamigaki of JARE-31, K. Saito of JARE-32 and 33, and the officers and crew of the icc-brcakcr Shirase.

This study was partly supported by a grant-in-aid (04640406) for scientific research from the Ministry of Education, Science and Culture, Japan. This is a contribution from the Satellite Remote Sensing and Occan Research Tcam, Japan Marine Science and Technology Center.

\section{REFERENCES}

Comiso, J.C. and A. L. Gordon. 1987. Recurring polynyas over the Cosmonaut Sea and Maud Rise. 7. Geophys. Res., 92 (C3), 2819-2833. Enomoto. H. and A. Ohmura. 1990. The influences of atmospheric halfyearly cycle on the sea ice extent in the Antarctic. 7. Geophys. Res.. 95 (C6), 9497-9511.

Khimitsa, V.A. 1976. Issledovaniye geostroficheskikh techeniye v Antarkticheskoy zone Indiyskogo Okeana [Study of geostrophic currents in the Antarctic zone of the Indian Occan]. Okennolngive, 16(2), 234-238.

Naganobu, M. 1991. Water structure of the Southern Ocean. Gekkan Kaiyo, 23, 715-733. [In Japanese.]

The accuracy of references in the text and in this list is the responsibility of the authors, to whom queries should be addressed. 